\title{
European Waste-to-Energy Systems \\ Case study of the Thermal Complex of Brive, France
}

\author{
Contract No.: EC-77-C-01-2103 \\ Prepared for: \\ Energy Research and Development Administration (ERDA) \\ Division of Buildings and Community Systems \\ Washington, D.C. 20545
}

Prepared by:

Resource Planning Associates, Inc.

Vashington, D.C.

June 1977

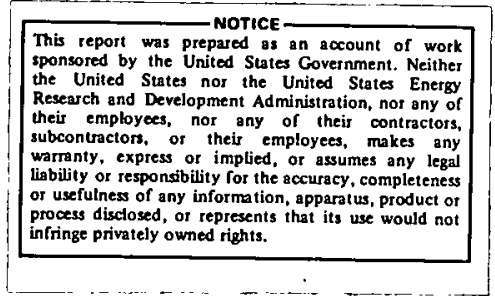




\section{DISCLAIMER}

This report was prepared as an account of work sponsored by an agency of the United States Government. Neither the United States Government nor any agency Thereof, nor any of their employees, makes any warranty, express or implied, or assumes any legal liability or responsibility for the accuracy, completeness, or usefulness of any information, apparatus, product, or process disclosed, or represents that its use would not infringe privately owned rights. Reference herein to any specific commercial product, process, or service by trade name, trademark, manufacturer, or otherwise does not necessarily constitute or imply its endorsement, recommendation, or favoring by the United States Government or any agency thereof. The views and opinions of authors expressed herein do not necessarily state or reflect those of the United States Government or any agency thereof. 


\section{DISCLAIMER}

Portions of this document may be illegible in electronic image products. Images are produced from the best available original document. 
LIST OF EXHIBITS

Page

$1 \mathrm{~b}$

WASTE TREATMENT COMPLEX OF BRIVE, FRANCE

2

DEVELOPMENT OF CURRENT WASTE TREATMENT SYSTEM

3

DESIGN OF THE WASTE TREATMENT SYSTEM

5

OPERATION OF THE WASTE TREATMENT SYSTEM

9

DESCRIPTION

Incineration

Waste-Wwater Treatment

11

Heat Recovery and Sludge Drying

13

Gaseous and Solid Emissions Control.

MANAGEMENT

16

EVALUÁTION OF SYSTEM EFFICIENCY AND RELIABILITY

COST OF THE SYSTEM

27

CAPITAL COSTS

DIRECT OPERATING COSTS

NOTES

PERSONS CONTACTED

CONVERSION TABLES 
1. Qualified Groups of Companies

2. View of the Complex

3. Technical Data Sheet

4. Section of the Incinerator and Sludge Drying Equipment

5. Sewage Treatment

6. Vertical Thin Film Sludge Dryer

7. Level of Particulate Emissions

8. Organization Chart of the Plant Work Force '

9. Manpower Schedule for the Incineration Plant in 1976 .

10. Monthly Variation in Quantity of Waste and sludge Incinerated (1975)

11. Quantity of Waste Incinerated

12. Energy Production and Use 22

13. Incinerator Manufacturer's Guarantee $\quad 25$

14. Nonroutine Maintenance Costs 26

15. Incinerator Breakdowns . . . . 26

16. Cost of Incinerator Unit 28 
WASTE TREATMENT COMPLEX OF BRIVE, FRANCE

Brive is a city of 55,000 inhabitants located in the Department of Corrèze, a low-population-density area in the south of France. It is the largest municipality in the department, but Tulles, a smaller agricultural town, is the administrative center. Brive lies in the intersection of two main transportation (i.e., water, highway, railroad) axes, one north-south and the other east-west, which explains its development, after World War II, from a rural town to a center of agribusiness and industry.

Brive has an area of $42 \mathrm{~km}^{2}(18.5 \mathrm{sq} \mathrm{mi})$, with an average density of 1,150 persons $/ \mathrm{km}^{2}(2,978$ persons/sq $\mathrm{mi})$. Except for the massed housing in the city center, the city is composed mainly of individual houses. An industrial area is located in the southwest section of the city, and there are small businesses in the southeast. The main industries are food processing, heavy manufacturing, and electronics.

Household waste is collected three times a week from about 100 communities (160,000 inhabitants) in the Brive area. A public organization, the Syndicat Intercommunal de Ramassage et de Traitment des Ordures Ménagères (SIRTOM), collects and treats the solid waste of 80 communities $(120,000$ inhabitants) including Brive and surrounding towns. SIROM, a public waste collection organization in Tulle, and SICTOM, a similar operation in Sarlat, collect waste from 20 communities $(40,000$ inhabitants) and transport it to transfer stations in Tulle and Sarlat, about $40 \mathrm{~km}(25 \mathrm{mi})$ from Brive. At those points, SIRTOM picks up the waste and transports it to Brive. This arrangement was launched in October 1974. It is an unusual experiment for France, and has not been without political and administrative problems. However, it is expected that other communities will join this scheme and that new transfer stations will be created.

SIRTOM employs 56 workers and uses 18 packer trucks to collect the waste from Brive and the surrounding area. The area is divided into 18 districts, each served by a packer truck and a 3-person crew. In Brive, plastic bags are used for collection. All household waste is burned in the incinerator. Some special waste, such as bulky waste, tires, grass, and leaves, is dumped in a noncontrolled landfill.

Waste collection and transportation are paid for by local taxes. Eách community contributes to the budgets of the collection organizations according to the number of hours of collection and the tonnage of waste transported. The cost of waste collection for Brive was $\operatorname{FFr} 1,381,600 *(\$ 289,000)$ in 1976 while the cost of transportation was FFr $429,000 * \approx(\$ 90,000)$. The cost of the plastic collection bags in 1976 was FFr $450,000(\$ 94,000)$. Thus, the total cost of waste collection and transportation in Brive was FFr 41 ( $\$ 8.60)$ per inhabitant, or FFr 174 per metric ton ( $\$ 33$ per short ton). in 1976 .

* FFr $88 / \mathrm{hr} \times 15,700 \mathrm{hr}$.

** FFr 33/metric ton $x 13,000$ metric tons 
The collected waste is transported to the waste treatment complex in Brive. To gain a clear understanding of the nature and operation of this complex, the remainder of this case study explains:

- How the current waste treatment system was developed

- The design of that system

- The way in which the system operates

- System costs.

\section{DEVELOPMENT OF CURRENT WASTE TREATMENT SYSTEM}

In the early 1960s, all of Brive's waste was dumped in a noncontrolled landfill. But because of complaints from neighbors and the frequent fires, the municipality decided in 1968 to find a new means of disposing of its solid waste. Controlled landfill was the least expensive solution, but no suitable location could be found. 1 And composting was rejected because of the fluctuation of prices resulting from the small number of potential buyers. 2

At the same time, Brive also needed to build a sludge treatment facility. The possibility of a joint facility for solid waste incineration and sludge treatment was suggested by M. Val, the director of Brive's technical services, when he learned that such a plant was being built in the French city of . Dieppe in 1969. M. Val, a young engineer who had visited a number of new waste treatment systems in France and other countries (including the U.S.), studied the technical and economic aspects of Dieppe's system and proposed certain changes. In particular, he felt that the incinerator should burn fresh instead of digested sludge*, as at Dieppe.

Preliminary studies were conducted to locate a suitable site for the solid waste and sludge treatment complex, and the municipality voted in favor of this combined system. Because this combination of solid waste incineration and sewage treatment was new, M. Val's persuasive arguments in favor of a joint facility were a decisive factor in making this solution acceptable at all levels. The fact that the mayor of Brive, $M$. Charbonel, was also the Minister of Industry in the French national government was helpful.

Preliminary studies of the solid waste incineration unit and sewage treatment unit were carried out in 1968 and early 1969 by M. Val and the technical services unit. The results of these studies were the basis for the bid invitation issued at the end of 1969. This bid invitation specified a joint facility for solid waste incineration and sludge treatment, using energy (heat) recovered from incineration to dry the sewage sludge which would subsequently be incinerated with the waste. ${ }^{3}$ It also specified that the contract to be awarded would include not only construction but also operation of the incineration and sludge treatment facility. The operation phase was included to obtain a better estimate of the overall cost of waste treatments and to take advantage of a tax benefit - specifically, to recover the value added tax (17.6 percent of the capital costs) - from operating the facility through a concession.

* A mixture of sewage solids and water that has been decomposed by anaerobic bacteria. 
Bidding was open to companies selected by prequalification. Five groups of companies were selected in June 1970. Six other companies that had qualified for only the incinerator or only the sewage treatment plant were asked to form groups and present joint bids. ${ }^{4}$

By December 1970, eight groups of companies had been judged qualified (see Exhibit 1): The municipality urged two of these firms, Société de Construction d'Usines d'Incineration d'Ordures Ménageres (INOR) the French representative of Von Roll of zurich, and Omnium d'Assainissement (ODA), one of the major French specialists in water treatment, to present' a joint bid, which they did in June 1971.

Exhibit 1

\section{Qualified Groups of Companies}

\begin{tabular}{lll}
\hline $\begin{array}{l}\text { Group } \\
\text { No. }\end{array}$ & Incinerator Contractor & $\begin{array}{l}\text { Waste-Water Treatment } \\
\text { Contractor }\end{array}$ \\
\hline $1:$ & INOR (representative of Von Roll) & INOR \\
2 & Tunzini (representative of VKW) & Degremont \\
3 & SFRIR & Degremont \\
4 & CNIM (representative of Martin) & CIE \\
5 & CEC & Omnium d'Assainissement \\
6 & SOFICO & Omnium d'Assainissement \\
7 & Stein Industries & Froment Clavier \\
8 & Luchaire & Luchaire \\
\hline
\end{tabular}

After eliminating several competitors for technical reasons, city officials had to decide between INOR/ODA and Degrèmont/SFRIR. Although the INOR/ODA bid was a little higher than that of Degremont/SFRIR, the equipment offered was considered more reliable. This was especially true of the vertical press filter and the vertical sludge dryers. Moreover, INOR had built the incinerator for the solid waste/sludge treatment complex at Dieppe. Consequently in July. 1971, the contract for construction and operation was awarded to INOR for the incineration unit and ODA for the sewage treatment unit. Construction of the incinerator began in November 1971, while construction of the sludge treatment unit began in May 1974. The incinerator began operations in september 1973, and the sludge treatment unit, in February 1975. 


\section{DESIGN OF THE WASTE TREATMENT SYSTEM}

The solid waste/sewage sludge treatment complex, an attractive design by a local architect, is situated on a 2.8 hectare $(7$ acre) tract in the western part of Brive (see Exhibit 2). It is about $4.8 \mathrm{~km}$ ( $3 \mathrm{mi}$ ) from the town center, at some distance from any residential area.

The main building, which houses the incineration and sludge drying operations, has an area of $500 \mathrm{~m}^{2}(5,380 \mathrm{sq} \mathrm{ft})$ and a volume of $12,000 \mathrm{~m}^{3}$ $(424,000 \mathrm{cu} \mathrm{ft})$. It is roughly L-shaped, with the operations and maintenance sections located in the middle and the filtration operation located in the inner angle of the $\mathrm{L}$. A separate building contains a truck-weighing scale, a laboratory, heating equipment for the main plant, and an administrative office.

The waste treatment complex is composed of a waste incineration unit, an energy recovery operation, a sewage treatment unit, a sludge drying unit, and a multicyclone to control particulate emissions (see Exhibit 3).

The incineration unit is equipped with two Von Roll furnaces, each capable of processing 3.5 metric tons ( 3.9 short tons) of waste per hour.* The two furnaces were designed to operate 7,000 hours per year, which would permit the incineration of 49,000 metric tons (54,000 short tons) of waste annually. In reality, the estimated quantity of waste treated in 1976 is 37,000 metric tons $(40,750$ short tons), or 75 percent of maximum capacity.

Energy is recovered by a socomas fire-tube boiler on top of each furnace. The rated capacity of each boiler is 9.7 metric tons (10.7 short tons) of saturated steam at 16 bars $(15.8 \mathrm{~atm})$ per hour. However, steam is actually produced at 10.5 bars $(10.4 \mathrm{~atm})$.

The steam is condensed in the sludge dryers, in the heat exchangers for incoming combustion air, or in air-cooled condensers. At present, from 4 to 4.5 metric tons (4.4 to 5 short tons) of steam per hour are not used and simply condensed. Condensate returns to the boiler, so that the boilers, the sludge dryers, the air preheaters, and the condensers form closed systems. The feedwater is drawn through a treatment unit which has a capacity of $2.5 \mathrm{~m}^{3}$ (660 gal) per hour.

The energy recovered during incineration is used to dry sludge from the sewage treatment unit in three vertical Luwa dryers. Each dryer has a rated capacity of drying $2.5 \mathrm{~m}^{3}(3.3 \mathrm{cu}$ yds) of sludge per hour from 89 percent moisture content to between 40 percent and 50 percent moisture content.' This dewatered sludge can be added to the regular solid waste for incineration.

* The original contract had called for two furnaces, each with a capacity of processing 3 metric tons ( 3.3 short tons) per hour. However, a cannery producing 40 metric tons ( 44 short tons) of solid waste and sewage per day opened in the region. Consequently, the hourly capacities of the two furnaces were increased. 


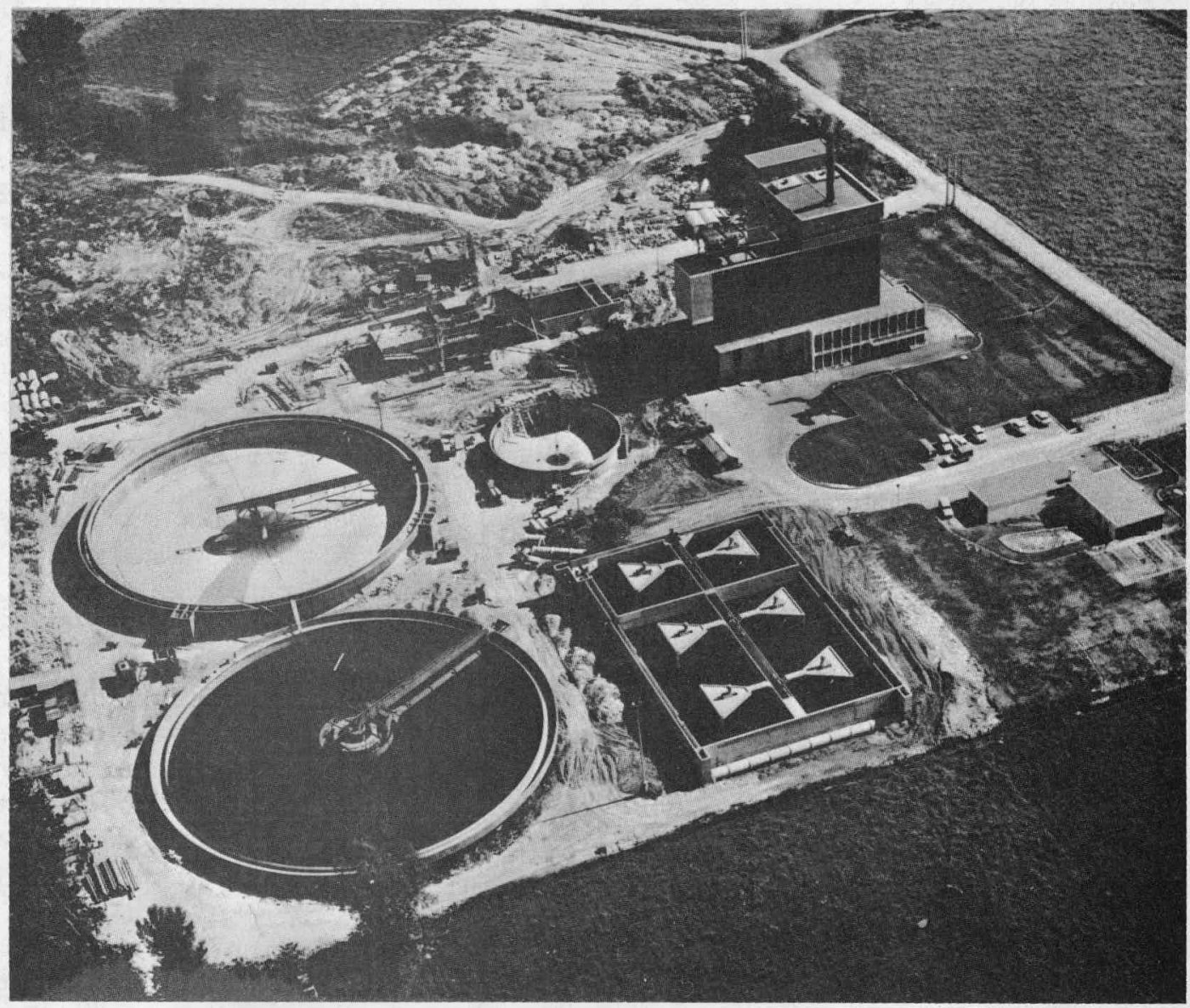




\section{Technical Data Sheet}

Dates

Start of construction

First incineration of solid waste

First incineration of sludge
November 1971

September 1973

February 1975

Metric System

2.8 hectares
$500 \mathrm{~m}^{2}$
$26 \mathrm{~m}$
$38 \mathrm{~m}$
$1.35 \mathrm{~m}$
$750 \mathrm{~m}^{3}$
$1.5 \mathrm{~m}^{3}$
4 metric tons
30 metric tons

6.9 acres

Plant dimensions

Area of site

Area of building

Height of furnace room

Height of smokestack

Diameter of smokestack

Volume of waste bunker

Volume of crane bucket

Capacity of crane bucket

Capacity of scale

30 metric tons

2

$16 \mathrm{~m}^{2}$
$50 \mathrm{~cm}$
$3.5 \mathrm{metric}$ tons per hour
$20,000 \mathrm{~m}^{3} / \mathrm{hr}$
$25,000 \mathrm{~m}^{3} / \mathrm{hr}$
$800^{\circ} \mathrm{C}$
$350^{\circ} \mathrm{C}$
$25,000 \mathrm{~m}^{3} / \mathrm{hr}$
$60 \%-70 \%$
150 metric tons

$172 \mathrm{sq} \mathrm{ft}$

$1.6 \mathrm{ft}$

3.9 short tons per hour

$706,200 \mathrm{cu}^{i} \mathrm{ft} / \mathrm{hr}$

$882,750 \mathrm{cu} . \mathrm{ft} / \mathrm{hr}$

$1472^{\circ} \mathrm{F}$

$662^{\circ} \mathrm{F}$

$882,750 \mathrm{cu} \mathrm{ft} / \mathrm{hr}$

165 short tons

2

9.7 metric tons per hour 16 bar

10.5 bar

$193^{\circ} \mathrm{C}$

3

10.7 short tons per hour

$15.8 \mathrm{~atm}$.

$10.4 \mathrm{~atm}$

$379^{\circ} \mathrm{F}$

$2.5 \mathrm{~m}^{3} / \mathrm{hr}$

Number of sludge dryers

Capacity of sludge dryers (from $89 \%$ moisture content to $45 \%$ moisture content)

\section{In addition to INOR, the following companies participated in the construction of the incineration unit:}

Construction

Structural steel work

Lighting

Locksmithing

Plumbing and heating

Facade

Steelwork for machinery

Overhead crane

Ventilation and air filtration

Ash removal

Electrical work

Condensors

Boiler

\author{
Roussel-Brive \\ Barbarin-Ruffec \\ Sobel-Brive \\ Sanz-Brive \\ Francy-Brive \\ Voisin \\ Barbarin-Ruffec \\ Reel-Lyon \\ Prat-Paris \\ Sanz-Brive \\ CGEE-Bordeaux \\ Creusot Loire-Paris \\ SOCOMAS-Hautmont
}

SOURCE: INOR 
The exhaust gasses pass from the incinerator through multicyclones located in the main building, to remove particulate emissions before escaping into the air through a smokestack 38 meters (125 ft.) high. These multicyclones, which have an efficiency of 60 - 70 percent, keep particulate emissions below 600 $\mathrm{mg} / \mathrm{m}^{3}$. The co content is less than 0.5 percent. 
Brive's waste treatment system is a relatively complex operation. To ensure complete understanding, we describe the system in detail, explain how it is managed, and summarize the results of evaluating its efficiency and reliability to date.

\section{DESCRIPTION}

The waste treatment complex has four distinct operations: incineration of solid waste (including dried sludge), treatment of waste-water, heat recovery and sludge drying, and emissions control. The interrelationship of the first three can be expressed as follows:

1 metric ton of

1.8 metric tons waste

lower heating value of $1,500 \mathrm{kcal} / \mathrm{kg}$

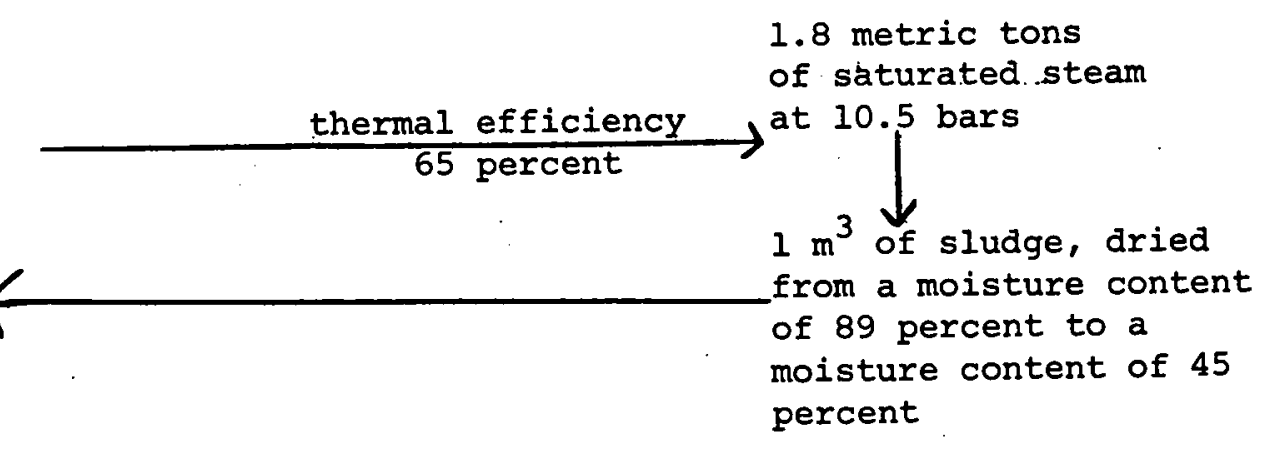

0.18 metric tons of dried siludge with a moisture content

of 45 percent and a lower heating value of $770 \mathrm{kcal} / \mathrm{kg}$

With the energy generated from incinerating 31,000 metric tons $(34,000$ short tons) of waste in 1975, it would have been possible to dry approximately $31,000 \mathrm{~m}^{3}(8,190,200 \mathrm{gal})$ of sludge (at 89 percent moisture content). However, because sewage comes only from Brive, only about $10,000 \mathrm{~m}^{3}(2,642,000 \mathrm{gal})$ of sludge was dried. This operation produced 1,900 metric tons $(2,090$ short tons) of dried sludge for subsequent incineration. ${ }^{5}$ In 1976 , approximately 37,000 metric tons $(40,750$ short tons) of waste were incinerated. With the energy generated, it would have been possible to dry approximately 37,000 $\mathrm{m}^{3}(9,775,000 \mathrm{gal})$ of sludge with a moisture content of 89 percent. However, only an estimated $16,000 \mathrm{~m}^{3}(4,227,200 \mathrm{gal})$ of sludge were dried, producing 3,000 metric tons $(3,300$ short tons $)$ of dried sludge. section.

Each of the four major operations is detailed in the remainder of this

\section{Incineration.}

Solid waste is brought by truck to the incinerator (see Exhibit 4 ) where it is weighed and then dumped into a waste pit with a volume of $750 \mathrm{~m}^{3}$ (981 cu $y d)$. This capacity allows up to 3 days' collected waste to be stored at any given time. There is no shredder.

A 4 - metric-ton (4.4 short ton) crane with a $1.5 \mathrm{~m}^{3}$ ( $1.96 \mathrm{cu}$ yd) bucket picks up the waste from the waste pit and puts it into the furnaces' water- 


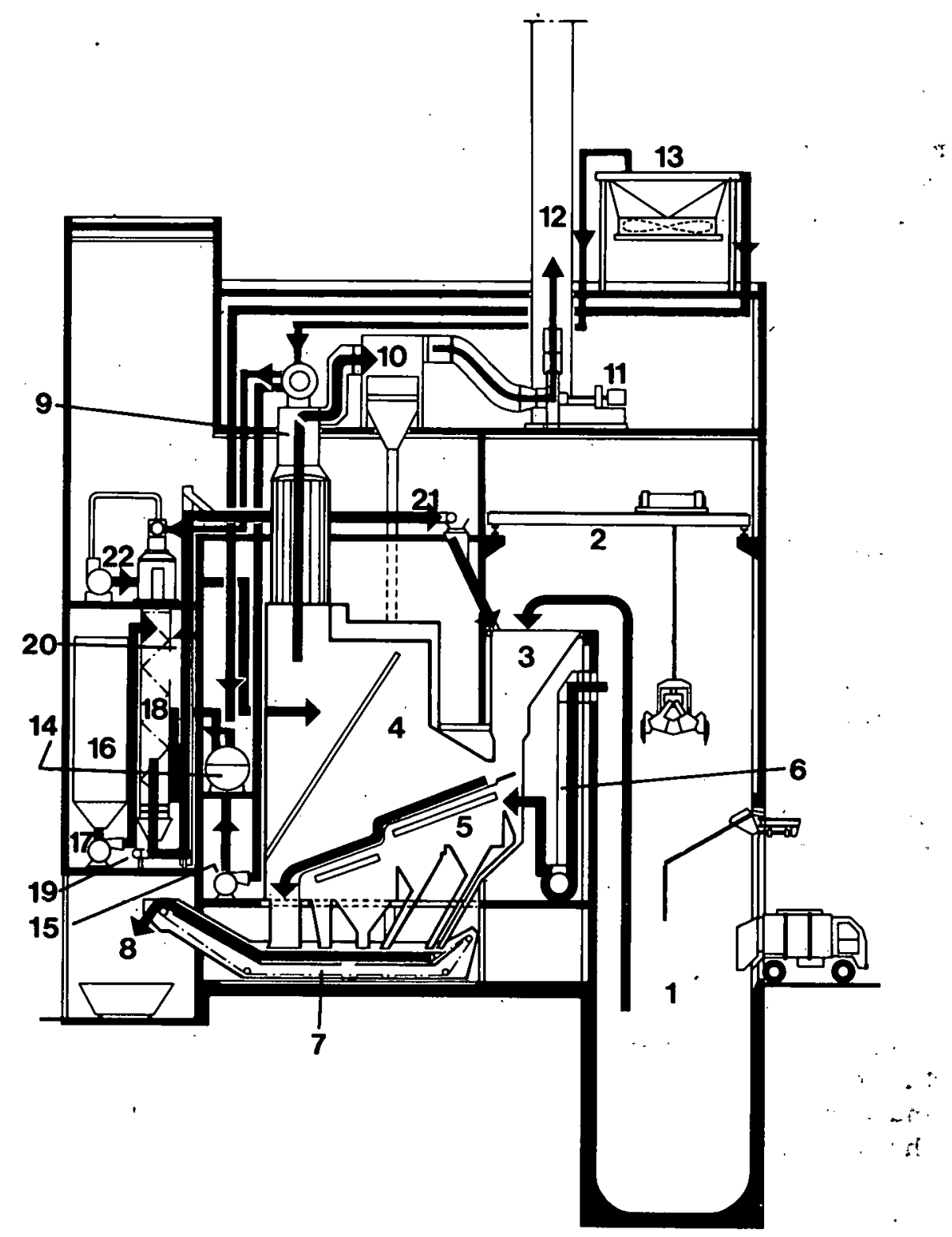

1. Waste pit.

2. Crane

3. Hopper

4. Combustion chamber

5. Grates

6. Combustion air fan

7. Ash trough

8. Ash discharge

9. Boiler

10. Cyclone battery
11. Induced draft fan

12. Stack

13. Condensor.

14. Condensate reservoir

15. Condensate pump

16. Sludge reservoir

17. Sludge pump
18. Sludge dryer

19. Conveyor belt

20. Hoist

21. Conveyor belt

22. Forced draft fan

SOURCE: INOR 
cooled hoppers $(1.80 \times 1.20 \mathrm{~m}$ or $5.9 \mathrm{ft} \times 3.9 \mathrm{ft})$, which have cast iron doors and feeders. 6 These hoppers also receive the dewatered sludge from the dryers. The furnace has a steel frame and plates, and is insulated with refractory bricks to a thickness of $50 \mathrm{~cm}(20 \mathrm{in})$.

From the hoppers, the waste and dried sludge drop onto the distribution grate; are moved to the combustion grate, through the use of two sections of fixed, hydraulically-driven chrome steel bars; and transported, via two more sections of the fixed and movable chrome steel bars, to the burn out grate. There is a $1.2 \mathrm{~m}(3.9 \mathrm{ft})$ step between the combustion grate and the burn out grate to ensure better combustion of the waste. The total area of the grates is $16 \mathrm{~m}^{2}$ (172 $\mathrm{sq} \mathrm{ft}$ ).

At the combustion grate, air, drawn from the waste pit and heated by a heat exchanger to a temperature of $150^{\circ} \mathrm{C}(3020 \mathrm{~F})$, is introduced under the grate and forced through the grate by a fan with a capacity of $20,000 \mathrm{~m}^{3} / \mathrm{hr}$ $(706,000 \mathrm{cu} \mathrm{ft} / \mathrm{hr})$. An oil-fired burner (150 kg or $330 \mathrm{lb}$ per hour) is used to initiate combustion. The thermal limit of each furnace is $7.3 \mathrm{Gcal}$ $\left(28.9 \times 10^{6} \mathrm{Btu}\right)$ per hour, which, in turn, imposes the 3.5 metric ton ( 3.9 short ton) per hour limit on capacity. Combustion temperature is $900^{\circ} \mathrm{C}$ $\left(1,620^{\circ} \mathrm{F}\right)$.

A fire-tube boiler is located on top of each combustion chamber so that the furnace and the boiler form an integrated system. Secondary air is introduced before the boiler to ensure complete burning of the gases before they are exhausted through the stack.

Combustion residues fall through four hoppers into a water-filled trough which seals the furnace. They are carried by a conveyer chain to a storage bin. Eventually, they are trucked to the landfill.

Waste-Water Treatment

Brive's combined sewage system handles residential and industrial sewage and storm drainage for the equivalent of a population of 160,000 . The average levels of pollution are $208 \mathrm{mg} / 1$ of $\mathrm{BOD}_{5}$ and $216 \mathrm{mg} / 1$ of suspended solids. The sewage, which contains 7.9 metric tons/day $\left(8.7\right.$ short tons/day) of BOD $_{5}$ and 8.2 metric tons/day ( 9 short tons/day) of suspended solids, is transported through the sewers to the waste-water treatment unit of the waste treatment complex. The treatment unit has an average daily flow of $38,000 \mathrm{~m}^{3} / \mathrm{hr}(10,039,600$ $\mathrm{gal} / \mathrm{hr})$ and a maximum hourly flow of $3,625 \mathrm{~m}^{3} / \mathrm{hr}(957,700 \mathrm{gal} / \mathrm{hr})$.

Waste-water enters the treatment facility through a lift station with three screw pumps, each having a capacity of $1,400 \mathrm{~m}^{3}(370,000$ gal) per hour (see Exhibit 5). The waste is "screened" by two rotating screens, each $2 \mathrm{~m}$ $(6.5 \mathrm{ft})$ in diameter. Grit is removed by mechanical scraper with an area of $81 \cdot \mathrm{m}^{2}$. (872. sq $\mathrm{ft}$ ) and a classifier. The waste-water continues to a primary sedimentation tank with a diameter of $50 \mathrm{~m}$ (164 ft) and a capacity of 6,850 $\mathrm{m}^{3}$. $(1,810,000 \mathrm{gal})$. After the waste-water is skimmed and is allowed to remain in the sedimentation tank for 2-3 hours, during which time it loses $30-35$ percent of its $\mathrm{BOD}_{5}$ and $60-65$ percent of its suspended solids, 


\section{Sewage Treatment}

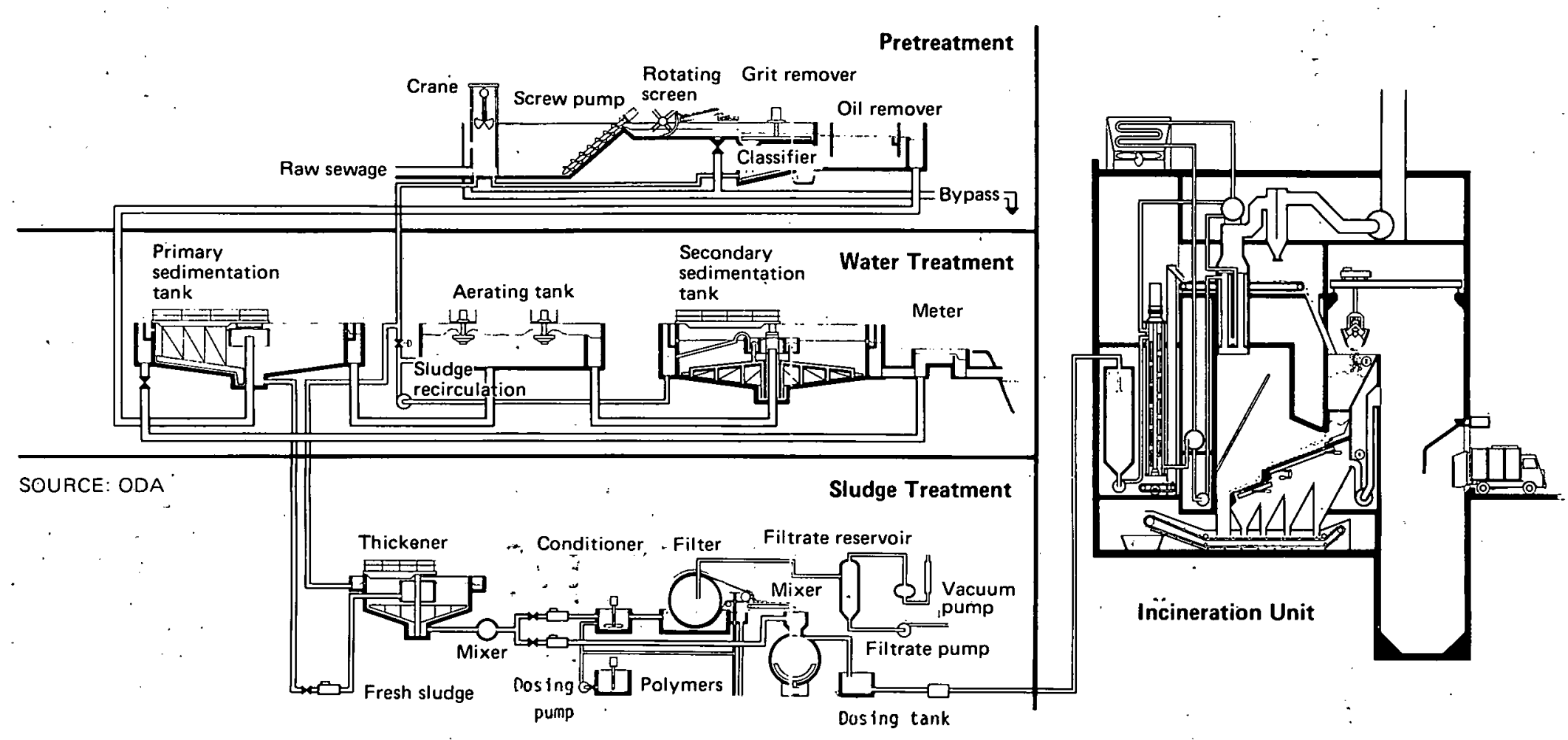


it is moved to aerating tanks, which have total capacity of $4,200 \mathrm{~m}^{3}(1,110,000$ gal). Six ODA Neyrpic turbine aerators, each with a diameter of $2.8 \mathrm{~m}$ (9 $\mathrm{ft}$ ) and driven by a 100-hp motor, activate the sludge in these tanks. The sludge then moves to a secondary sedimentation tank with a diameter of $50 \mathrm{~m}$ (164 ft) and a capacity of $7,850 \mathrm{~m}^{3}(2,070,000 \mathrm{gal})$, but is recirculated into the aerating tanks, if necessary, to maintain the desired concentration of activated sludge regardless of the degree of pollution in the waste-water as it enters the treatment unit.

The effluent is piped into the nearby Correze River, while the sludge from both the primary and secondary sedimentation tanks goes to a thickener, having diameter of $20 \mathrm{~m}(66 \mathrm{ft})$ and a capacity of $940 \mathrm{~m}^{3}(248,000 \mathrm{gal})$. In the thickener, the moisture content of the sludge is lowered to approximately 94 percent. 7 some of the thickened sludge goes to a vertical press filter for chemical treatment by polyelectrolysis, * which reduces its moisture content to approximately 80 percent. Sludge from this process ( 80 percent moisture. content) is combined with sludge that comes directly from the thickener (94 percent moisture content) to obtain a homogenous mixture with a moisture content of 88.6 percent. This mixture is pumped into the dryers. There has been no attempt to lower the moisture content of the sludge any further because the vertical thin film dryers require that the sludge remain relatively fluid at entry.

\section{Heat Recovery and Sludge Drying}

The thickened sludge from the waste-water treatment unit is pumped to tanks located at the tops of the three stainless steel vertical thin film sludge driers (each of which has a capacity of $2.5 \mathrm{~m}^{3} / 3.3 \mathrm{cu}$ yd per hour of sludge) in the drying unit, which is located in the same building as the incinerator (see Exhibit 4). The sludge is then pumped into the top of the dryer cylinder. As it flows down through the cylinder, the sludge is spread over the inner surface by a rotor carrying self-adjusting vanes, revolving at a speed of $250 \mathrm{rpm} .8$ The cyclinder is surrounded by a steam jacket fed from the boilers of the waste-burning furnaces (see Exhibit 6). That is, the heat recovered during incineration enters the boilers, which have a heat exchange surface of $240 \mathrm{~m}^{2}\left(2,582 \mathrm{sq} f \mathrm{ft}\right.$ apiece, at $700^{\circ} \mathrm{C}\left(1,2820^{\mathrm{F}}\right)$. Each boiler produces 9.7 metric tons (10.7 short tons) per hour of steam at a pressure of 10.5 bars $(10.4 \mathrm{~atm})$. The steam is used to dry the sludge and the dryers thus serve as condenser for the boilers:

The vapors generated in the dryers travel upward and are extracted by fans through outlet tubes at the dryer heads. They pass into the incinerators as overfire air where they are deodorized at a temperature above $800^{\circ} \mathrm{C}$ $\left(1,472^{\circ} \mathrm{F}\right)$.

The dewatered sludge contains only 40-50 percent moisture, and has a lower heating value of approximately $770 \mathrm{kcal} / \mathrm{kg}(1,390 \mathrm{Btu} / \mathrm{lb})$. Thus, it can be incinerated along with the solid waste: To this end, dried sludge granules fall onto a conveyor belt under the dryers (see Exhibit 4), and are carried automatically to the hopper of one of the furnaces. In this operation, even distribution and constant feed are necessary for total combustion and satisfactory furnace operation.

* However, the shortage of sludge, mentioned above, has led the plant operator to bypass filtration for some of the sludge. 
Exhibit 6

Vertical Thin Film Sludge Dryer

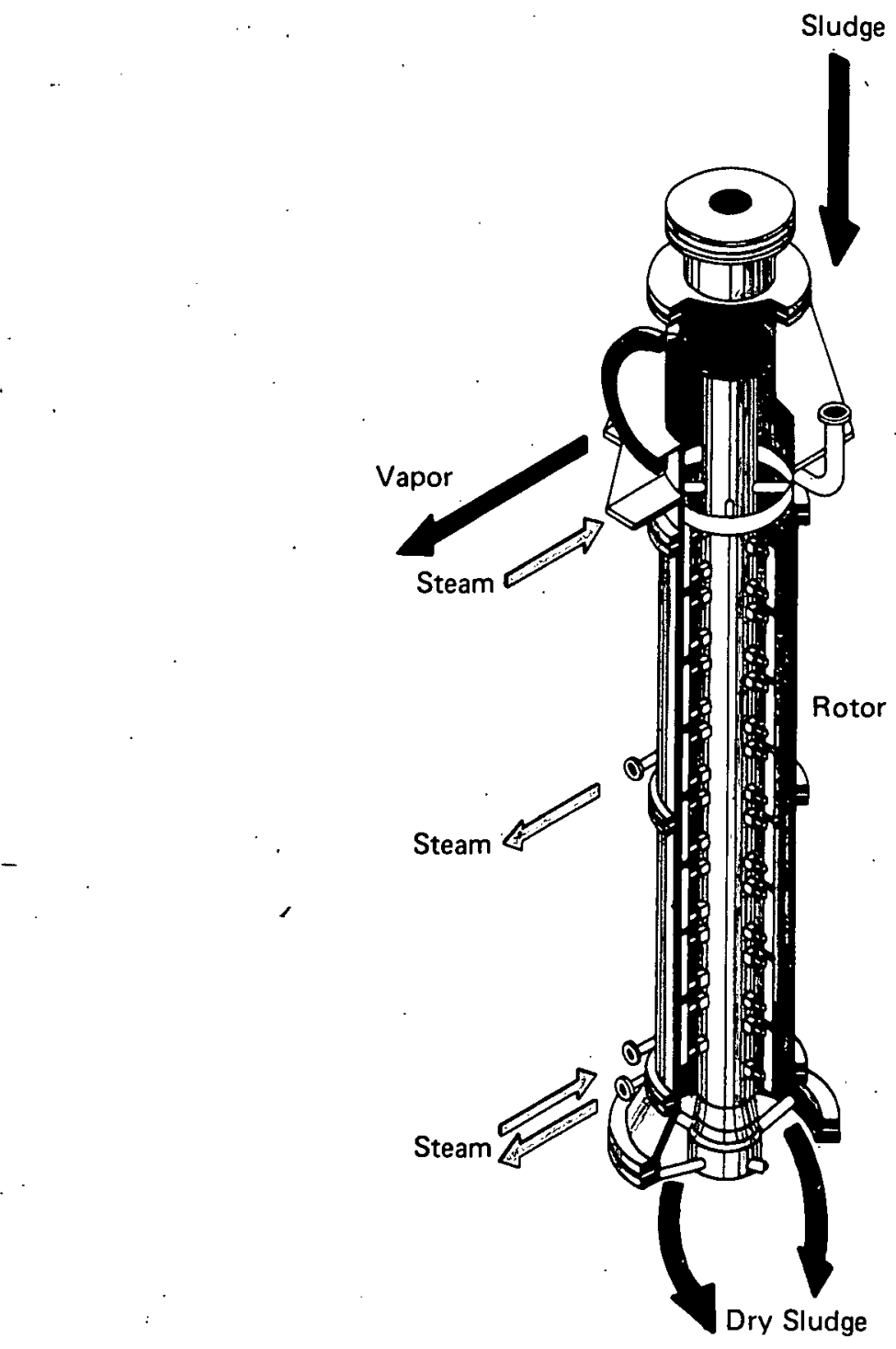

14 


\section{Gaseous and Solid Emissions Control}

Exhaust gases from incineration are produced at the rate of $25,000 \mathrm{~m}^{3}$ $(882,750 \mathrm{cu} f t)$ per hour per furnace. The gas leaves the boiler at a temperature of $350^{\circ} \mathrm{C}\left(662^{\circ} \mathrm{F}\right)$ and is drawn through the multicyclone by a fan with an output of $28,000 \mathrm{~m}^{3}(988,680 \mathrm{cu} \mathrm{ft})$ per hour. The multicyclone reduces particulate emissions to an average of $350 \mathrm{mg} / \mathrm{m}^{3}$ at 7 percent $\mathrm{CO}_{2}$ which corresponds to an efficiency of 60-70 percent. ${ }^{9}$ These levels are in accord with the French legislation for plants of this size (Circulaire du 6 juin 1972). The gas escapes through a 38 meter (125 ft) smokestack having a diameter of 1.35 meter $(4.4 \mathrm{ft})$. The smokestack is separated into two flues, corresponding to the two furnaces, to obtain a constant flow even when only one furnace is in operation. The CO content is guaranteed to be under 0.5 percent.

Particulate emissions were measured at the stack level at the inauguration of the plant (i.e., in October 1973). The tests, which were carried out by the Louis Prat Company (Paris), showed that the emissions contained 17 percent water, 4 to 6 percent $\mathrm{CO}_{2}$, and between $184 \mathrm{mg} / \mathrm{m}^{3}$ and $545 \mathrm{mg} / \mathrm{m}^{3}$ of particulate, and had a $\mathrm{Ph}$ of approximately 2 (see Exhibit 7 ). 10

\section{Level of Particulate Emissions}

\begin{tabular}{|c|c|c|c|c|c|c|}
\hline & $\begin{array}{l}\text { Measurement } \\
\text { Number }\end{array}$ & $\begin{array}{l}\text { Operating } \\
\text { Capacity } \\
\text { of Furnace } \\
\text { (metric } \\
\text { tons*/hr) }\end{array}$ & $\begin{array}{l}\text { Gas } \\
\text { Temperature } \\
\left({ }^{\circ} \mathrm{C}\right)\end{array}$ & $\begin{array}{l}\text { Average } \\
\text { Speed } \\
(\mathrm{m} / \mathrm{s})\end{array}$ & $\begin{array}{l}\text { Gas } \\
\text { Output } \\
\left(\mathrm{m}^{3} / \mathrm{hr}\right)\end{array}$ & $\begin{array}{l}\text { Particulate } \\
\text { Level } \\
\left(\mathrm{mg} / \mathrm{m}^{3}\right)\end{array}$ \\
\hline \multirow[t]{8}{*}{ Furnace No. 1} & 1 & 3.5 & 230 & 14.9 & 20.800 & 545 \\
\hline & 2 & 3.5 & 230 & 14.8 & 20.600 & 225 \\
\hline & 3 & 3.5 & 230 & 16.5 & 23.000 & 430 \\
\hline & 4 & 3.5 & 230 & 16.4 & 22.900 & 184 \\
\hline & 5 & 2.0 & 200 & 8.4 & 12.500 & 390 \\
\hline & 6 & 2.0 & 200 & 8.8 & 13.100 & 383 \\
\hline & 7 & 2.0 & 230 & 14.2 & 19.800 & 282 \\
\hline & 8 & 2.0 & 230 & 9.2 & 13.150 & 500 \\
\hline \multirow[t]{8}{*}{ Furnace No. 2} & 1 & 3.5 & 250 & 10.8 & 14.500 & 360 \\
\hline & 2 & 3.5 & 250 & 10.8 & 14.500 & 260 \\
\hline & 3 & 3.5 & 230 & 10.8 & 15.150 & 230 \\
\hline & 4 & 3.5 & 250 & 12.3 & 16.500 & 270 \\
\hline & 5 & 3.5 & 250 & 12.3 & 16.500 & 295 \\
\hline & 6 & 2.0 & 200 & 8.6 & 12.800 & 450 \\
\hline & 7 & 2.0 & 215 & 12.0 & 16.900 & 395 \\
\hline & 8 & 2.0 & 200 & 6.8 & 10.150 & 495 \\
\hline
\end{tabular}

SOURCE: INOR records.

*To convert metric tons to short tons, multiply by 1.1 . 
In addition to the exhaust gases, which contain some air pollution elements, incineration residue is produced in the waste treatment process. On average, incineration residue equals 37 percent, by weight ( 16 percent by volume), of the waste treated.11 The water content is about 50 percent. (The incinerator manufacturer guarantees an average of less than 0.5 percent putrescible materials and less than 5 percent unburned materials, 12 but no measurement has been made to see if these limts are realized.) This residue has been used to build embankments, although the presence of steel cans limits this application. The recovery of ferrous materials from the ashes has also been considered, but it is economically infeasible in such a small operation.

\section{MANAGEMENT}

INOR manages the incinerator and sludge dryer and ODA operates the sewage treatment unit, in accordance with the 20-year concession in the original contract. However, INOR takes the lead in managing the complex, and the chief of operations is an INOR employee who lives at the site (see Exhibit 8). Brive exercises its overall control through its technical service unit, which is in direct contact with the chief of operations, who provides the city with monthly operational records and yearly technical reports. 13

Fifteen people are employed at the waste treatment complex: the chief of operations; 11 people employed by INOR at the incineration unit; and 3 people, employed by ODA, at the sewage treatment unit (see Exhibit 9).* of the 11 people working at the incineration unit, 6 operate the incinerator and sludge dryers, 2 are maintenance men, 1 is a janitor, 1 is a clerk, and 1 is a truck driver. The 6 incinerator operators are organized into three 2-man shifts, each working 8 hours a day. In each shift, one worker controls furnace operations and the other introduces the waste into the furnace. The clerk supervises the weighing of trucks and the truck driver hauls the incineration residue to the dump. INOR provides a replacement furnace operator during
vacations.

At the beginning of operations, Von Roll and INOR engineers spent only about 3 months instructing the personnel in the proper operation and maintenance of the highly automated furnaces. According to the chief of operations, a worker can learn to operate the incinerator and sludge dryers in a few months. However much more experience is necessary to deal with the operating and maintenance problems that arise.

* This dual employment structure has apparently led to problems of competency and coordination; as a result, in practice, each group works almost independently. 


\section{Organization Chart of the Plant Work Force}

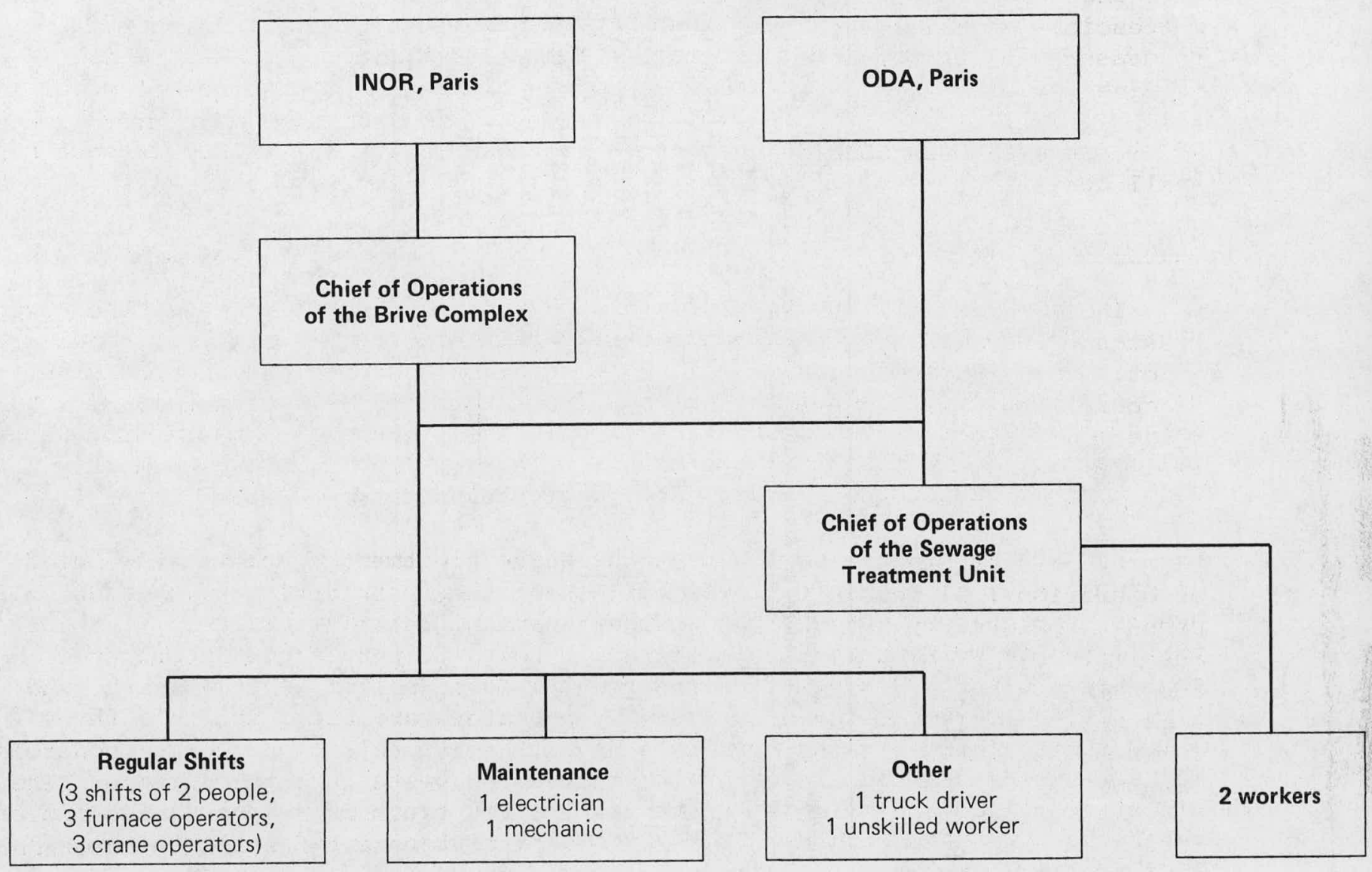

SOURCE: INOR 
Manpower Schedule for the Incineration Plant in 1976

(hours)

\begin{tabular}{|c|c|c|c|c|c|c|c|}
\hline & $\begin{array}{l}\text { Furnace } \\
\text { Operation }\end{array}$ & $\begin{array}{l}\text { Sludge } \\
\text { Dryers } \\
\text { Operation }\end{array}$ & $\begin{array}{l}\text { Routine } \\
\text { Maintenance } \\
\end{array}$ & $\begin{array}{l}\text { Nonroutine } \\
\text { Maintenance }\end{array}$ & Administration & Others & Total \\
\hline January & 676 & 320 & 482 & 118 & 359 & - & 1,955 (11 employees) \\
\hline February & 757 & 240 & 382 & 40 & 335 & - & 1,754 (11 employees) \\
\hline March & 876 & 160 & 535 & 20 & - & - & 1,591 (11 employees) \\
\hline April & 826 & 160 & 607 & 60 & 372 & - & 2,025 (11 employees) \\
\hline May & 721 & 200 & 320 & 120 & 351 & 314 & $\mathbf{2 , 0 2 6}$ (12 employees) \\
\hline June & 940 & 120 & 405 & - & 349 & 170 & 1,984 (12 employees) \\
\hline July & 978 & 88 & 135 & 108 & 346 & 178 & 1,833 (10 employees) \\
\hline August & 983 & 70 & 181 & 30 & 183 & 136 & 1,583 ( 9 employees) \\
\hline September & 1,000 & 80 & 240 & - & 276 & - & 1,596 (11 employees) \\
\hline October & 1,016 & 80 & 255 & - & 265 & - & 1,620 (10 employees) \\
\hline Total & 8,773 & 1,518 & 3,542 & 496 & 2,836 & 798 & 17,967 \\
\hline
\end{tabular}


EVALUATION OF SYSTEM EFFICIENCY AND RELIABILITY

The incinerator began operations at the end of 1973 and burned only waste during 1974. In 1973, 1,300 metric tons (1,430 short tons) of waste were incinerated. In 1974, the first full year of operations, 23,100 metric tons (25,440 short tons), including 20,800 metric tons $(22,900$ short tons) of household waste and 2,300 metric tons $(2,530$ short tons) of commercial and industrial waste brought in by private companies were burned. In 1975, a total of 29,100 metric tons $(32,070$ short tons), including 27,400 metric tons $(30,200$ short tons) of household waste collected by the waste collection organizations and 1,700 metric tons (1,870 short tons) of commercial and industrial waste was incinerated. (The monthly variations during that period are shown in Exhibit 10.) During the first 10 months of 1976, 27,000 metric tons $(29,740$ short tons) of waste were burned, including 25,600 metric tons $(28,200$ short tons) of household waste and 1,400 metric tons (i,540 short tons) of commercial and industrial waste (see Exhibit 11):

In February 1975, the sewage treatment unit and the sludge dryers began operation. In that first year, 1,970 metric tons $(2,170$ short tons) of sludge were incinerated, while 2,100 metric tons $(2,300$ short tons) were burned. during the first 10 months of 1976 (see Exhibit 12). Accordingly, the total amount of incinerated solid waste and sludge was 1,300 metric tons $(1,430$ short tons) in 1973, 23,100 metric tons $(25,400$ short tons) in 1974, 31,070 metric tons $(34,240$ short tons) in 1975 , and 29,350 metric tons $(32,000$ short tons) during the first 10 months of 1976. Theoretically, with two furnaces operating at full capacity $(7,000 \mathrm{hr} /$ year $) * 49,000$ metric tons (54,000 short tons) of waste could be treated. In 1976, approximately 37,000 metric tons $(40,750$ short tons) were incinerated - 34,000 metric tons $(37,400$ short tons) of solid waste and 3,000 metric tons $(3,300$ short tons) of dried sludge. This amounts to 75 percent of maximum capacity, or almost 80 percent of the manufacturer's rated capacity of 43,000 metric tons (47,400 short tons) per year.

The increase in the quantity of waste treated is the result of new communities' joining Brive's collection and treatment scheme. Indeed, at the rate of planned growth, the capacity of the incineration unit may be insufficient by the end of 1978,14 and a third furnace will be necessary.

* The manufacturers and the municipality estimate that a minimum of 30,000 metric tons (33,000 short tons) per year is necessary to justify 24-hour-aday operations. When operating around the clock, the plant is shut down at $4 \mathrm{a} . \mathrm{m}$. on Saturday mornings. One week out of two it is started up again at $4 \mathrm{a} . \mathrm{m}$. on Monday. In alternate weeks, Monday is used for routine maintenance and operations begin again Monday evening. 


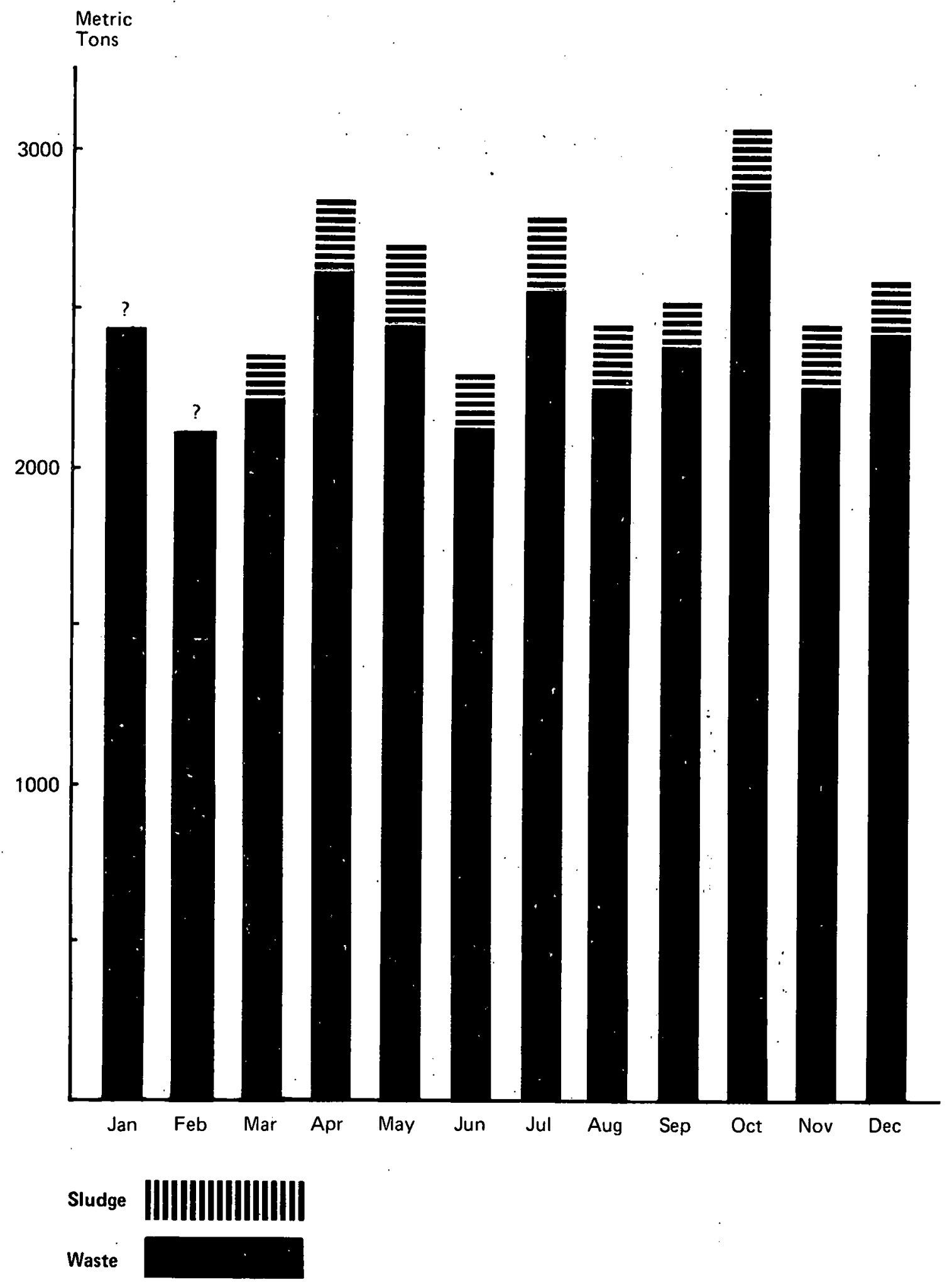


Quantity of Waste Incinerated

(January-October 1976)

\begin{tabular}{|c|c|c|c|c|c|c|c|}
\hline \multirow[b]{2}{*}{ Operating Period } & \multirow{2}{*}{$\begin{array}{l}\text { Quantity } \\
\text { of Waste } \\
\text { Incinerated } \\
\text { (metric tons)* }\end{array}$} & \multirow{2}{*}{$\begin{array}{l}\text { Quantity } \\
\text { of Sludge } \\
\text { Incinerated** } \\
\text { (metric tons) }\end{array}$} & \multirow{2}{*}{$\begin{array}{l}\text { Total } \\
\text { Incinerated } \\
\text { (metric tons) }\end{array}$} & \multicolumn{2}{|c|}{ Furnace Operations (hr) } & \multirow{2}{*}{$\begin{array}{l}\text { Total } \\
\text { (hr) }\end{array}$} & \multirow{2}{*}{$\begin{array}{l}\text { Average } \\
\text { (metric } \\
\text { tons/hr) }\end{array}$} \\
\hline & & & & 1st Furnace & 2nd Furnace & & \\
\hline January & 2,567 & 195 & 2,762 & 464 & 460 & 924 & 3.0 \\
\hline February & 2,289 & 272 & 2,561 & 426 & 426 & $8 \dot{52}$ & 3.0 \\
\hline March & 2,694 & 215 & 2,909 & 488 & 488 & 976 & 3.0 \\
\hline April & 2,586 & 261 & 2,847 & 463 & 463 & 926 & 3.1 \\
\hline May & 2,435 & 228 & 2,663 & 451 & 450 & 501 & 3.0 \\
\hline June & 2,808 & 238 & 3,046 & 517 & 519 & 1,036 & 2.9 \\
\hline July & 2,920 & 177 & 3,097 & 533 & 513 & 1,046 & 3.0 \\
\hline August & 2,910 & 182 & 3,092 & 516 & 517 & 1,033 & 3.0 \\
\hline September & 2,917 & 208 & 3,125 & 530 & 530 & 1,060 & 2.9 \\
\hline October & 3,100 & 154 & 3,254 & 538 & 538 & 1,076 & 3.0 \\
\hline Total & 27,226 & 2,130 & 29,356 & 4,926 & 4,904 & $9 ; 430$ & \\
\hline
\end{tabular}

SOURCE: INOR

* To convert to short tons, multiply by 1.1 .

* *At 40-50 percent moisture content. 


\section{Energy Production and Use}

(January-October 1976)

\begin{tabular}{|c|c|c|c|c|c|c|c|c|}
\hline \multirow[b]{2}{*}{$\begin{array}{l}\text { Period of } \\
\text { Operation }\end{array}$} & \multirow{2}{*}{$\begin{array}{l}\text { Quantity } \\
\text { of Waste } \\
\text { Incinerated } \\
\text { (metric tons)* }\end{array}$} & \multirow{2}{*}{$\begin{array}{l}\text { Quantity } \\
\text { of Sludge } \\
\text { Incinerated } \\
\text { (metric tons) }\end{array}$} & \multirow{2}{*}{$\begin{array}{l}\text { Energy } \\
\text { Content } \\
\text { of Waste } \\
\left(10^{6} \mathrm{kcal}\right)\end{array}$} & \multirow{2}{*}{$\begin{array}{l}\text { Production } \\
\text { of Steam** } \\
\text { (metric tons) }\end{array}$} & \multicolumn{3}{|c|}{ Steam Use $\left(10^{6} \mathrm{kcal}\right)^{\dagger}$} & \multirow{2}{*}{$\begin{array}{l}\text { Heat } \\
\text { Recovery } \\
\text { Ratef } \\
\text { (percent) }\end{array}$} \\
\hline & & & & & $\begin{array}{l}\text { Sludge } \\
\text { Drying }\end{array}$ & $\begin{array}{l}\text { Air } \\
\text { Preheating }\end{array}$ & Condensor & \\
\hline January & 2,567 & 195 & 4,001 & 7,228 & 955 & 1,345 & 1,748 & 24 \\
\hline February & 2,289 & 272 & 3,643 & 6,000 & 1,790 & 1,240 & 329 & 49 \\
\hline March & 2,694 & 215 & 4,207 & 6,290 & 1,514 & 1,421 & 587 & 36 \\
\hline April & 2,586 & 261 & 4,080 & 5,556 & 1,526 & 1,348 & 237 & 37 \\
\hline May & 2,435 & 228 & 3,828 & 5,413 & 1,114 & 1,312 & 605 & 29 \\
\hline June & 2,808 & 238 & 4,395 & 6,092 & 1,167 & 1,509 & 736 & 27 \\
\hline July & 2,920 & 177 & 4,516 & 5,884 & 970 & 1,113 & 1,212 & 21 \\
\hline August & 2,910 & 182 & 4,505 & 5,874 & 1,005 & 1,099 & 1,185 & 22 \\
\hline September & 2,917 & 208 & 4,536 & 5,874 & 1,142 & 1,128 & 1,019 & 25 \\
\hline October & 3,100 & 154 & 4,769 & 6,182 & 846 & 1,145 & 1,472 & 18 \\
\hline Total & 27,226 & 2,130 & 42,480 & 60,393 & 12,029 & 12,660 & 9,130 & \\
\hline
\end{tabular}

SOURCE: RPA estimates based on INOR records.

* To convert to short tons, multiply by 1.1 .

**Although the production of steam is measured constantly, these figures are based on the number of hours of actual operation.

† To convert kcal to Btu, multiply by 3.9685 .

₹ The heat recovery rate equals the amount of heat actually used to dry sludge divided by the heat content of the waste. 
The energy content of the waste incinerated during the first 10 months of 1976 was $42,480 \times 10^{6} \mathrm{kcal}\left(165,580 \times 10^{6} \mathrm{Btu}\right)$. The heat (energy) actually recovered and sent to the sludge dryers during that period was equal to 12,000 $\times 10^{6} \mathrm{kcal}\left(47,600 \times 10^{6} \mathrm{Btu}\right)$. This equals a 28 percent energy recovery rate, * assuming the waste has a lower heating value of $1,500 \mathrm{kcal} / \mathrm{kg}(2,700 \mathrm{Btu} / \mathrm{lb}) . *$ * Experience has shown that rural areas like Brive produce a significant amount of damp grass and leaves for processing which may create combustion problems and necessitate extending drying time on the first grate.*** However, the lower heating value of the waste has increased with the adoption of plastic bag collection in Brive, since the plastic bags not only protect the refuse from any further inclement weather but also produce intense heat when burned with the waste.

The saturated steam produced in the heat-recovery process is at 10.5 bars (10.4 atm) not the 16 bars (15.8 atm) stipulated in plant specifications. The energy content of the steam is assumed to be $560 \mathrm{kcal} / \mathrm{kg}(1,008 \mathrm{Btu} / \mathrm{lb})$. The amount of this used in the sludge dryers has varied considerably from monthto-month - a 2:1 ratio between February 1976 and october 1976 - because of differences in the quantity and composition of the sludge. Thus, the amount of steam required to dry one cubic meter $(1.3 \mathrm{cu} y d)$ of sludge ranges from 1.6 metric tons to 2.3 metric tons ( $1.75-2.5$ short tons), or an average of 1.8 metric tons per $\mathrm{m}^{3}$ ( 1.5 short tons per $\left.\mathrm{cu} y d\right) .15$ The resulting dried sludge (with a moisture content of 40-50 percent) has a lower heating value of 770 $\mathrm{kcal} / \mathrm{kg}(1,390 \mathrm{Btu} / \mathrm{lb})$, while the lower heating value of the solid portion of the sludge is estimated at $2,730 \mathrm{kcal} / \mathrm{kg}(4,900 \mathrm{Btu} / \mathrm{lb}) .16$

The average thermal efficiency of the incinerator and boiler is between 60 percent and 66 percent, depending on the lower heating value of the waste incinerated. (If the value is low, more energy is required for preheating combustion air.) A lower heating value of $1,300 \mathrm{kcal} / \mathrm{kg}(2,340 \mathrm{Btu} / \mathrm{lb})$ gives a thermal efficiency of 60 percent, and a lower heating value of $1,600 \mathrm{kcal} / \mathrm{kg}$ $(2,880 \mathrm{Btu} / \mathrm{lb})$ or above gives a thermal efficiency of 66 percent. 17 This level of efficiency could be improved if a better balance could be achieved between the amount of waste incinerated and the amount of sludge treated. As it is, the amount of energy produced from incineration exceeds the amount of energy needed for sludge drying. Brive has plans to build municipal greenhouses near the waste treatment complex and heat them with the steam not used for drying sludge.

* This figure varied from 18 percent to 49 percent per month, depending on the sludge drying requirement.

** Estimated by the plant operator; no measurement has been made.

*** However, the heating value of waste at any incineration site will vary somewhat over time. Such variations may occur because the composition of the waste can vary considerally by season or as a result of economic conditions. For example, when the cost of paper increases, paper is recycled rather than discarded as waste. Since paper has a relatively high heat content its absence from the waste stream might result in waste of lower heat content. 
However, a thermal balance over a period of a year does not ensure a balance on every single day. At Brive, sludge must remain in the thickener near the limit of capacity, over the weekends when no waste is incinerated.

In terms of reliability, the system performed well during the early years of operation. (See Exhibit 13 for the manufacturer's guarantee on the parts and operation of the incinerator.) Specifically, during the first 3 years of operation, nonroutine maintenance costs amounted to FFr 441,000 $(\$ 92,260 ; 1976)$, including $\operatorname{FFr} 131,000(\$ 27,400 ; 1976)$ to replace the multicyclones after 12,000 hours of operation, or FFr 5.2 metric ton ( $\$ 1$ per short ton) incinerated (see Exhibit 14). The manufacturer claims nonroutine maintenance costs generally run FFr 8 - 10 per metric ton $(\$ 1.50-\$ 1.90 ; 1976$ per short ton.) 18 And during roughly the first 2 years of operation, waste incineration had to be suspended for only 634 hours (see Exhibit 15). 19

However, by 1976 the refractory walls of each furnace had been severely damaged. Approximately $18 \mathrm{~m}^{2}$ (194 sq $\mathrm{ft}$ ) of refractory material will have to be replaced in the upper part of each furnace. According to the municipality, the expansion joints failed to prevent distortion of the furnace walls at high temperature. 20 According to the manufacturer, the problems have occurred because the sludge filtration step is partly bypassed and sludge enters the driers with a higher moisture content than anticipated. In addition, evaporated water is circulated to the furnaces to eliminate odors, and thus the furnaces receive more water vapor when the sludge dryers are operating than had been expected.

But regardless of the cause, it will cost about $\operatorname{FFr} 500,000 \quad(\$ 105,000 ; 1976)$ to replace the damaged sections of the refractory walls. With this repair, the cost of nonroutine maintenance will amount to 10 percent of the cost of the incinerator.

Finally, after 3 years operating experience, it appears the environment of the complex is quite acceptable. Although there is some odor in the vicinity of the sludge dryers, it does not spread to the rest of the plant. Moreover, with the help of outside specialists, the operational noise that was inaudible at the plant but could be heard several miles away* has been eliminated. And, very importantly, no major accident has ever occurred at the Brive facility.

* A fan produced a peculiar resonance. 


\section{Incinerator Manufacturer's Guarantee}

Von Roll guarantees its furnaces under the following provisions:

- The lower heating value of the waste incinerated must be between 1,000 and 2,500 $\mathrm{kcal} / \mathrm{kg}(1,800-4,500 \mathrm{Btu} / \mathrm{lb})$

- The moisture content of the waste must be under 50 percent

- The carbon content of the waste must be under 5 percent

- The ash content of the waste must be under 40 percent

- The combustible content of the waste must be over 25 percent.

Under these conditions, Von Roll guarantees that:

- Each furnace will have a capacity of 3.5 metric tons (3.9 short tons) per hour

- Putrescible materials in the residues of incineration will be under 0.5 percent by weight

- Unburned materials in the residues of incineration will be under 5 percent by weight

- The temperature of incineration will be at least $700^{\circ} \mathrm{C}\left(1,292^{\circ} \mathrm{F}\right)$

- The particulate content of the stack gas will not be more than $600 \mathrm{mg} / \mathrm{m}^{3}$ at 7 percent $\mathrm{CO}_{2}$

- The $\mathrm{CO}$ content of the gas will not be more than 0.5 percent

- The electricity required for incineration will not be more than $40 \mathrm{kWh}$ per metric ton (36.3 kWh per short ton) of waste.

Mechanical equipment is guaranteed for one year. 


\section{Nonroutine Maintenance Costs}

(as of December 1976)

\begin{tabular}{llc}
\hline & FFr & $\mathbf{1 9 7 6 ~ \$ ~}$ \\
\hline $\begin{array}{l}\text { Replacement parts for grates, ash } \\
\text { chain conveyor, and furnaces }\end{array}$ & 217,500 & 45,500 \\
Replacement of multicyclone & & \\
-for Furnace 1 & 75,000 & 15,690 \\
-for Furnace 2 & 56,000 & 11,715 \\
Replacement of refractory & 92,500 & 19,355 \\
\hline Total & $\mathbf{4 4 1 , 0 0 0}$ & $\mathbf{9 2 , 2 6 0}$ \\
\hline
\end{tabular}

SOURCE: INOR

\section{Incinerator Breakdowns}

\begin{tabular}{lcc}
\hline & \multicolumn{2}{c}{ Downtime } \\
Cause & $\mathbf{1 9 7 4}$ & $\mathbf{1 9 7 5}$ \\
\hline Steam network failure & 22 & 8 \\
Crane failure & 70 & 77 \\
Grate failure & 21 & 37 \\
Boiler failure & 30 & 78 \\
Multicyclone failure & 30 & 57 \\
Hopper failure & 22 & 17 \\
Electrical circuit failure & 16 & 5 \\
Ash extractor failure & 10 & 6 \\
Lack of water & 12 & 6 \\
Lack of electricity & 11 & 14 \\
Masonry failure & 26 & 47 \\
Lack of waste & - & 12 \\
\hline Total & $\mathbf{2 7 0}$ & $\mathbf{3 6 4}$ \\
\hline
\end{tabular}

SOURCE: Municipality of Brive. 
The total cost of the complex, exclusive of the land which belonged to the municipality, was FFr 30 million: ( $\$ 6$ million; 71-74') FFr 11.2 million ( $\$ 2.2$ million; 71-'74) for the incineration unit, FFr 14 million ( $\$ 2.85$ million; 71-'74) for the sewage treatment unit, and FFr 4.8 million $(\$ 950,000 ; 71-174)$ for the sludge dryers. Government subsidies paid for 50 percent of the cost of the incineration unit: the Ministry of the Interior provided 30 percent, and the Department of Correze provided 20 percent. For a while, the law permitted the recovery of some of the taxes because the complex was managed by a private company, but this is no longer the case. Subsidies for the sewage treatment unit and sludge dryers amounted to 55 percent of the costs - a 30-percent subsidy from the Ministry of Interior and a 25-percent subsidy from the local water pollution agency of the Adour-Garonne Basin (Agence Financiere de Bassin Adour-Garonne).

The rest of the funding was obtained through 20-year loans, primarily from the Caisse des Dépóts et Consignations, which plays the role of state banker for such project at relatively low interest rates $(7.8$ percent in this case). In addition Société Générale provided a FFr 1.7 million bank loan at 8.05 percent. Thirty-seven percent of the cost of the incinerator unit was expended in 1972; 55 percent, in 1973; 7 percent, in 1974; and 1 percent, in 1975 .

The overall cost of incineration in 1975 was FFr $59.5 /$ metric ton $(\$ 12.60$; 1975 /short ton) incinerated, based on approximately 30,000 metric tons $(33,000$ short tons) incinerated annually. This cost is composed of the capital cost of FFr $27.5 /$ metric ton $(\$ 5.83 ; 1975 /$ short ton)* plus the direct operating cost of FFr $32 /$ metric ton ( $\$ 6.77 ; 1975 /$ short ton).

\section{CAPITAL COSTS}

Although the original contract for the incineration unit stipulated a capital cost of FFr 9.5 million ( $\$ 1.7$ million; 1971) (see Exhibit 16), Brive eventually paid FFr 11.2 million** for the unit because of labor and material cost increases. This "overrun" was allowable under an escalator clause in the contract and the contract was revised according to an index for construction costs.

The sewage treatment unit cost FFr 14 million ( $\$ 2.5$ million; 1971).** of this, FFr $800,000(\$ 145,000 ; 1971)$ was spent on the sludge dryers, excluding installation.

\section{DIRECT OPERATING COSTS}

Brive pays INOR four kinds of waste-incineration fees, the amounts of which are based on the quantity of waste to be incinerated and, consequently, on the number of shifts required, as shown in the following matrix.

\footnotetext{
*Based on amortization cost, including debt service, of FFr 800,000 over 20 years.

**Including a value added tax at the rate of 17.6 percent.
} 


\section{Cost of Incinerator Unit}

(1971 prices)

\begin{tabular}{|c|c|c|c|}
\hline & $\mathrm{FFr}$ & $\mathrm{FFr}$ & 1971 \$ \\
\hline Construction & & $2,340,000$ & 424,700 \\
\hline $\begin{array}{l}\text { Equipment } \\
\text {-Scale } \\
\text {-Waste pit doors } \\
\text {-Overhead crane } \\
\text {-Ash extractor } \\
\text {-Furnaces } \\
\text {-Steam boilers } \\
\text { - Cyclone battery } \\
\text {-Control equipment } \\
\text {-Electrical equipment } \\
\text {-Other equipment }\end{array}$ & $\begin{array}{r}58,800 \\
84,700 \\
318,000 \\
282,200 \\
3,082,300 \\
764,400 \\
515,100 \\
224,600 \\
382,200 \\
252,800\end{array}$ & $5,965,100$ & $1,082,600$ \\
\hline Access roads & & $369,500^{*}$ & 67,000 \\
\hline Administration building & & $155,000^{*}$ & 28,300 \\
\hline Add-on for increase in capacity of furnaces & & 658,000 & 119,400 \\
\hline Total & & $9,487,600 * *$ & $1,722,000$ \\
\hline
\end{tabular}

SOURCE: INOR; City of Brive.

* Fifty percent of total cost; remaining 50 percent allocated to waste-water treatment unit costs.

** Including a 17.6 percent value added tax. 
Incineration Fees Paid to INOR

(rates in effect in March 1975)

\begin{tabular}{|c|c|c|}
\hline Type of Fee & $\begin{array}{l}\text { Quantity of Waste } \\
15,000-30,000 \text { metric } \\
2 \text { shifts per day }\end{array}$ & 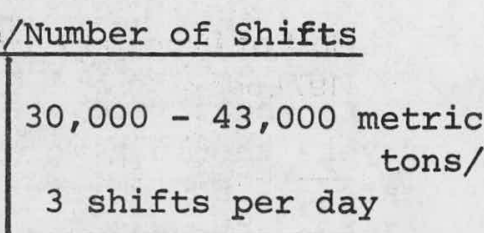 \\
\hline $\begin{array}{l}\text { A fixed fee for operation } \\
\text { and routine maintenance }\end{array}$ & $\begin{array}{l}\text { FFr } 424,000 / \text { annum } \\
\quad(\$ 98,800 / \text { annum }\end{array}$ & $\begin{array}{c}\text { FFr } 832,000 / \text { annum } \\
(\$ 193,900 / \text { annum })\end{array}$ \\
\hline $\begin{array}{l}\text { An additional fee for operation } \\
\text { and routine maintenance propor- } \\
\text { tional to the tonnage of waste } \\
\text { treated }\end{array}$ & $\begin{array}{l}\text { FFr } 10.47 / \text { metric ton } \\
\quad(\$ 2.22 / \text { short ton })\end{array}$ & $\begin{array}{l}\text { FFr } 14.93 / \text { metric ton } \\
(\$ 3.16 / \text { short ton })\end{array}$ \\
\hline $\begin{array}{l}\text { A fixed fee for nonroutine } \\
\text { maintenance and replacement } \\
\text { parts }\end{array}$ & $\begin{array}{l}\text { FFr } 39,000 / \text { annum } \\
(\$ 9,000 / \text { annum })\end{array}$ & $\begin{array}{l}\text { FFr } 136,000 / \text { annum } \\
(\$ 31,700 / \text { annum })\end{array}$ \\
\hline $\begin{array}{l}\text { An additional fee for non- } \\
\text { routine maintenance and re- } \\
\text { placement parts proportional } \\
\text { to the tonnage of waste treated }\end{array}$ & $\begin{array}{l}\text { FFr } 3.24 / \text { metric ton } \\
\text { (\$0.69/short ton) }\end{array}$ & $\begin{array}{l}\text { FFr } 3.24 / \text { metric ton } \\
\quad(\$ 0.69 / \text { short ton })\end{array}$ \\
\hline
\end{tabular}

This fee schedule was established in the original contract and is revised quarterly, with an average increase of approximately 1 percent per month.

In 1975, approximately 31,000 metric tons (34,000 short tons) of waste were incinerated: 27,400 metric tons $(30,200$ short tons) of household waste, 1,700 metric tons (1,870 short tons) of commercial and industrial waste, and 1,900 metric tons (2,090 short tons) of dried sludge. The cost of the incineration of household waste and dried sludge, as billed by INOR, was FFr 1.5 million $(\$ 350,000 ; 1975)$, or FFr $51.2 /$ metric ton $(\$ 10.83 ; 1975 /$ short ton) incinerated: fixed fees of FFr 968,000 and proportional fees of FFr 532,000. The actual cost to the city was somewhat less, as INOR collects FFr 48 per metric ton ( $\$ 10.15 ; 1975$ per short ton) of industrial waste received from private generators and returns FFr 6 per metric ton ( $\$ 1.25 ; 1975$ per short ton) to the city. Thus, in 1975, the city received an additional FFr 10,200 $(\$ 2,375 ; 1975)$ which should be deducted from the fees it pays INOR. The actual cost to the city is therefore FFr 50.8 per metric ton $(10.75 ; 1975$ per short ton). Brive paid the fixed and proportional fees directly to INOR and then allocated them among the municipalities participating in the collection/ 
incineration program, according to the quantity of waste collected in each community.

If this heat were not available the municipality would have to purchase an equivalent amount of energy in order to dry siudge. Therefore, the value of the heat recovered from the incineration process and used in the sludge dryers should be credited towards these costs. For example in 1975, an estimated 22,500 metric tons $(24,800$ short tons) of steam were used for drying sludge. Based on a price of FFr $25 /$ metric ton $(\$ 5.30 ; 1975 /$ short ton) of steam, this amounts to FFr $560,000(\$ 130,500 ; 1975)$ or FFr $19.1 /$ metric ton ( $\$ 4.04 ; 1975 /$ short ton) of waste incinerated.21 This would have reduced fees to the municipalities to FFr 32 metric ton $(\$ 6.77 ; 1975 /$ short ton) of sludge and household waste.

Brive also pays INOR an annual fixed fee of $\operatorname{FFr} 133,000 \quad(\$ 27,800 ; 1976)$ for operating the sludge dryers and a proportional fee of FFr $0.0056 / \mathrm{m}^{3}$ ( $(\$ 0.0009 ; 1976 / \mathrm{cu} \mathrm{yd})$ of sludge treated. This cost excludes the price of the steam which is obtained at no additional costs. 
1. Private communication: Mr. Val, Director of the technical services of the Municipality of Brive.

2. Private communication: Mr. Allemandour, engineer, technical services of the Municipality of Brive.

3. Municipal records: Devis progromme de concours pour la construction d'une usine d'incinération et d'une station d'épuration.

4. Municipal records: Procés verbaux des réunions successives du jury de concours.

5. PPA estimates based on INOR operating records.

6. Municipal records: Devis descriptif équipement-incinération.

7. ODA: Vizze de Brive, Station d'épuration.

8. M. Krings (INOR), French Experience with Facilities for Combined Processing of Municipal Refuse and Sludge.

9. Private communication: Mr. Gargallo, chief of operations of the complex (INOR).

10. Private communication: Mr. Allemandour.

11. INOR operating records.

12. Municipal records: Mémoire technique - incinération.

13. Private communication: Mr. Arbruster, director, INOR.

14. Private communication: $\mathrm{Mr}$. Val.

15. INOR operating records.

16. Private communication:- Mr. Arbruster.

17. Private communication: Mr. Arbruster.

18. Private communication: Mr. Arbruster.

19. INOR operating records.

20. Private communication: Mr. Val.

21. RPA estimates based on INOR operating records. 


\section{Persons Contacted}

The following individuals have cooperated with RPA in preparing this case study:

Mr. Val, Director of Technical Services, Municipality of Brive

Mr. Allemandou, Principal Engineer, Technical Services, Municipality of Brive

Mr. Armbruster, Director, INOR

Mr. Gargallo, Chief of Operation of the waste treatment complex, INOR

Mr. Amouroux, Operator of the sewage treatment unit, ODA 
English to Metric Conversions

\begin{tabular}{ll} 
To Convert & Multiply By \\
\cline { 2 - 2 } ton (short) & .9078 \\
feet & .3048 \\
square feet & .0929 \\
cubic feet & .0283 \\
cubic yards & .7646 \\
gallons & .003785 \\
square miles & 2.59 \\
atmospheres & 1.0133 \\
British thermal units & .252 \\
British thermal units & $2.52 \times 10^{-7}$ \\
British thermal units & 1055
\end{tabular}

To Obtain

ton (metric)

meters

square meters

cubic meters

cubic meters

cubic meters

square kilometers

bars

kilocalories

kilotherms

joules

Metric to English Conversions

To Convert

ton (metric)
meter
square meter
cubic meter
cubic meter
cubic meter
square kilometer
bar
kilocalorie
kilotherm
joule
kilowatt-hour

Multiply By

1.102

3.281

10.76

35.31

1.308

264.2

0.386

0.987

3.9685

$3.97 \times 10^{6}$

$9.486 \times 10^{-4}$

1.1
To Obtain

ton (short)

feet

square feet cubic feet cubic yards gallons

square miles atmospheres British thermal units British thermal units British thermal units Therms 
French Francs to U.S. Dollars

Year

1969

1970

1971

1972

1973

1974

1975

1976
$F / \$$

5.20

5.53

5. 51

5.04

4.45

4.81

4.29

4.78

Abbreviations

k Kilo thousand

$M$ mega million

G giga billion

m mili one thousandth

Source: "International Financial Statistics" International Monetary Fund. 